\title{
PERSEPSI GURU TENTANG PENGGUNAAN E-BOOK DALAM PEMBELAJARAN TKJ (TEKNIK KOMPUTER DAN JARINGAN )
}

\author{
Wahyu Mustaqim ${ }^{1}$, M. Ihsan Dacholfany ${ }^{2}$, Sudirman Amini ${ }^{*}$ \\ ${ }^{123}$ Universitas Muhammadiyah Metro \\ E-mail: $\quad$ mams.nepo@gmail.com ${ }^{1)}$ \\ muhammadihsandacholfany@ gmail.com ${ }^{2)}$ \\ sudirman.am57@gmail.com $^{3 *}$
}

\begin{abstract}
Abstrak
Penelitian ini mengambil fokus yaitu persepsi guru tentang penggunaan $e$-book (1) dalam pembelajaran TKJ (teknik komputer dan jaringan) (2) di SMK Negeri 1 Gedung Aji Kabupaten Tulang Bawang. Penelitian ini dilaksanakan mulai tanggal 22 Maret 2021 sampai tanggal 2 April 2021. Menggunakan metode kualitatif dengan pendekatan penelitian berjenis fenomenologi, yaitu mengungkap fenomena yang terjadi terkait fokus penelitian. Populasi penelitian ini adalah guru SMK Negeri se-Kecamatan Gedung Aji. Sementara untuk penentuan sampel menggunakan purposive sampling. Pengumpulan data dilakukan melalui wawancara. Keabsahan data menggunakan triangulasi sumber. Teknik analisis data meliputi (1) mengorganisasikan data (2) membaca dan membuat memo (3) mendeskripsikan, mengklasifikasi dan menafsirkan data (4) menyajikan data. Adapun kerangka penelitian yang digunakan memakai Technology Acceptance Model (TAM) yang berfokus pada mobilitas, fasilitas, resistance to change dan self efficacy. Hasil penelitian ini adalah sebagai berikut. guru SMKN 1 Gedung Aji mempersepsikan penggunaan $e$-book sebagai (a) kemudahkan mencari bahan ajar (efikasi diri), (b) dapat memberi wawasan yang luas (efikasi diri), (c) sesuai dengan kebutuhan (mobilitas), (d) variasi dengan berbagai sumber lainnya (mobilitas, dan fasilitas), (e) efisiensi penggunaan e-book menurut guru SMKN 1 Gedung Aji tergantung umur dan zaman pemakainya (resistance to change), (2) Kendala yang dirasakan guru yaitu jaringan internet yang lemah, membutuhkan kapasitas memori yang besar, memerlukan perangkat elektronik yang canggih, membutuhkan baterai handphone yang besar, membutuhkan kuota Internet yang banyak dan ukuran font yang kecil.
\end{abstract}

Kata kunci: Teknik Komputer dan Jaringan; Persepsi, e-book, Guru; Technology Acceptance Model

\begin{abstract}
This study focuses on the teacher's perception of the use of e-books (1) in TKJ learning (computer and network engineering) (2) at SMK Negeri 1 Gedung Aji, Tulang Bawang Regency. This research was conducted from March 22, 2021 to April 2, 2021. Using qualitative methods with a phenomenological type of research approach, which is to reveal the phenomena that occur related to the focus of the research. The population of this research is the teachers of SMK Negeri in Gedung Aji District. Meanwhile, to determine the sample using purposive sampling. Data collection was carried out through interviews. The validity of the data used source triangulation. Data analysis techniques include (1) organizing data (2) reading and making memos (3) describing, classifying and interpreting data (4) presenting data. The research framework used uses the Technology Acceptance Model (TAM) which focuses on mobility, facilities, resistance to change and self-efficacy. The results of this study are as follows. SMKN 1 Gedung Aji teachers perceive the use of e-books as (a) ease of finding teaching materials (self-efficacy), (b) can provide broad insights (self-efficacy), (c) according to needs (mobility), (d) variations with various other sources (mobility, and facilities), (e) efficient use of e-books according to the SMKN 1 Gedung Aji teacher depending on the age and age of the user (resistance to change), (2) The constraints felt by teachers are weak internet networks, requiring large memory capacity, requires sophisticated electronic devices, requires a large cellphone battery, requires a large Internet quota and a small font size.
\end{abstract}

Keywords: Computer and Network Engineering; Perception, e-books Teachers, Technology Acceptance Model. 


\section{PENDAHULUAN}

Meningkatkan sumber daya manusia salah satunya adalah dengan memberikan pendidikan yang menarik dan inovatif. Tidak hanya monoton menggunakan satu media pembelajaran saja. Semakin banak variasi pilihan akan semakin baik. Karena memperkaya khasanah dan referensi peserta didik dalam belajar. Namun demikian, seiring dengan kemajuan teknlogi, belum banyak guru yang mampu untuk mengimbanginya. Hal tersebut karena masih banyaknya guru yang terjebak pada metode lama yang tidak menyesuaikan perkembangan zaman.

Meski demikian, apabila diamati dari banyaknya kebijakan yang telah dikeluarkan oleh pemerintah baik dari undang - undang hingga turunannya telah banyak memberikan kontribusi dalam upaya peningkatan kualitas sumber daya manusia melalui peningkatan sistem pendidikan nasional. Terlebih semenjak era reformasi, anggaran untuk dunia pendidikan jauh lebih meningkat dari pada sebelumnya. Sehingga sangat dimungkinkan untuk diterapkan berbagai upaya guna mencapai tujuan pendidikan nasional melalui berbagai program - program menarik, kreatif dan invatif.

Tidak terkecuali bagi program pendidikan di sekolah vokasi atau sekolah menengah kejuruan. Lebih menekankan pada pembelajaran yang menekankan kemampuan atau skill baik soft skill maupun hard skill. Secara garis besar, proses pembelajaran di jenjang pendidikan sekolah menengah kejuruan menekankan pada program keahlian atau kompetensi. Tentu berkaitan erat dengan skill atau kemampuan terhadap bidang keahlian yang dipelajari. Baik softskill maupun hardskill melatih dan mengasah peserta didik agar mahir dan terampil terkait berbagai hal yang telah dipelajari. Hal tersebut dikarenakan pendidikan pada tingkat SMK menekankan sumber daya manusia sebagai lulusan yang siap kerja. Sejalan dengan Undang - Undang Pendidikan Nasional nomor 20 tahun 2003 pada pasal 15 menyatakan bahwa "pendidikan kejuruan adalah pendidikan yang mempersiapkan peserta didik terutama untuk dapat bekerja dalam bidang tertentu dan siap pula melanjutkan ke tingkat pendidikan yang lebih tinggi".

Oleh sebab itu, kekayaan literasi dalam proses pembelajaran di SMK menjadi sangat diperlukan. Hal tersebut bertujuan agar wawasan mengenai berbagai disiplin ilmu yang dipelajari diperoleh semaksimal mungkin sehingga peserta didik mempunyai gambaran yang utuh terhadap apa yang sedang dipelajari. Pemanfaatan e-book sebagai salah satu bentuk media pembelajaran yang ringkas dan mudah digunakan, membuat media yang satu ini layak untuk digunakan sebagai pelengkap sekaligus tambahan dalam proses pembelajaran.

Dengan demikian, jika dikaitkan dengan proses pembelajaran di sekolah menengah kejuruan (SMK) pemanfaatan e-book sebagai penunjang kegiatan pembelajaran kenyataannya belum berjalan dengan maksimal. Hal tersebut dapat dilihat dari hasil observasi awal sebagai data prasurvey pada tanggal 16 - 20 November 2020 yang dilakukan peneliti menunjukkan bahwa guru kejuruan yang telah memanfaatkan ebook di Sekolah Menengah Kejuruan Negeri 1 Gedung Aji hanya terbatas pada jurusan Teknik Komputer dan Jaringan. Hal tersebut diperkuat dengan penyampaian oleh ketua jurusan Teknik Komputer dan Jaringan dari SMK Negeri 1 Gedung Aji. Mereka belum memanfaatkan e-book dengan baik dan maksimal. Ketidakmaksimalan tersebut karena guru jarang memberi pelajaran tambahan atau tugas yang berkaitan dengan penggunaan e-book serta memberi himbauan kepada peserta didik agar sering memanfaatkan e-book dalam proses pembelajaran. Akhirnya, dari hasil pengamatan didapati guru - guru 
cenderung untuk membaca buku paket yang sudah ada di sekolah daripada menggunakan e-book.

\section{METODE PENELITIAN}

Jenis penelitian adalah penelitian kualitatif dengan metode fenomenologi. Penelitian fenomenologi menurut Wahyuni (2012:9) adalah penelitian yang berfokus pada pengalaman subjektif seseorang dan makna merupakan isi penting yang muncul dari pengalaman kesadaran manusia. Dengan menggunakan metode ini peneliti dapat mengetahui pemahaman mengenai konsep dan fenomena (Marshall \& Rossman, 2011), termasuk pendapat, karakteristik, perilaku dan pengetahuan (Fontana \& Prokos, 2007) serta pengalaman (Turner III, 2010).

Untuk itu, peneliti menggunakan metode fenomenologi karena terkait dengan pengalaman yang di rasakan guru mengenai penggunaan e-book pada pembelajaran teknik komputer dan jaringan. Tentu ada banyak hal yang dapat ditarik benang merah terkait perspektif guru terhadap penggunaan media pembelajaran. Mengingat strategi penggunaan media pembelajaran yang tepat, dapat meningkatkan keaktifan dan prestasi belajar peserta didik.

Sumber data merupakan salah satu yang paling vital dalam penelitian. Kesalahan dalam menggunakan atau memahami sumber data, maka data yang diperoleh juga akan meleset dari yang diharapkan. Sumber data meliputi dua jenis, pertama sumber data primer yaitu data yang diperoleh langsung dari objek penelitian, yaitu dari guru dan kedua data sekunder yaitu data-data yang diperoleh dari komponen sekolah seperti kepala sekolah, perangkat sekolah dan tenaga kependidikan.

Penelitian kualitatif menggunakan data berupa keterangan dari informan sesuai dengan pedoman wawancara yang diperoleh peneliti. Maka data yang didapat dalam penelitian kualitatif berupa transkrip wawancara. Sebagaimana diketahui sumber data pada jenis penelitian kualitatif adalah informan yang dijadikan sampel dalam penelitian.

Informan yang dijadikan sumber data dalam penelitian penggunaan e-book ini adalah guru di jurusan Teknik Komputer dan Jaringan, SMK Negeri 1 Gedung Aji. Jumlah sampel pendidik yang digunakan sebagai informan adalah sebanyak 5 orang. Sementara untuk tenaga kependidikan meliputi Kepala Sekolah, Wakil Kepala Sekolah Bidang Kesiswaan dan Wakil Kepala Sekolah Bidang Kurikulum. Peserta didik yang digunakan sebagai informan berjumlah 7 orang di masing-masing jenjang.

Pengumpulan data tidak lain dari suatu proses pengadaan data primer untuk keperluan penelitian. Pengumpulan data merupakan langkah yang amat penting diperoleh dalam metode ilmiah, karena pada umumnya data yang dikumpulkan digunakan, kecuali untuk penelitian eksploratif, untuk menguji hipotesa yang telah dirumuskan. Data yang dikumpulkan harus cukup valid untuk digunakan.

Metode pengumpulan data adalah teknik atau cara yang dapat digunakan oleh peneliti untuk mengumpulkan data, serta instrumen pengumpulan data adalah alat bantu yang dipilih dan digunakan oleh peneliti dalam kegiatannya mengumpulkan data agar kegiatan tersebut menjadi sistematis dan lebih mudah.

Pengumpulan data adalah prosedur yang sistematik dan standar untuk memperoleh data yang diperlukan. Perlu dijelaskan bahwa pengumpulan data dapat dikerjakan berdasarkan pengalaman. Secara metodologis dikenal beberapa macam tehnik pengumpulan data, diantaranya :

1. Observasi Penelitian 
Observasi adalah teknik pengumpulan data yang dilakukan melalui suatu pengamatan, dengan disertai pencatatan-pencatatan terhadap keadaan atau perilaku obyek sasaran. Metode observasi yatu melakukan pengamatan secara langsung ke obyek penelitian untuk melihat dari dekat kegiatan yang dilakukan oleh pendidik dan tenaga kependidikan selama proses pembelajaran.

Peneliti menggunakan observasi terus terang (overt observation) kepada sumber data, sehingga informan tahu sejak awal hingga akhir tentang aktifitas peneliti. Tahapan observasi meliputi observasi deskriptif, yaitu semua data direkam sehingga bentuk data belum tertata (grand tour observation). Selanjutnya tahap reduksi yakni mempersempit atau memfokuskan aspek yang akan diteliti. Dan terakhir adalah tahap seleksi, yakni menguraikan fokus yang ditemukan sehingga datanya lebih rinci.

2. Wawancara Penelitian

Wawancara adalah bentuk komunikasi antara dua orang yang melibatkan seseorang yang ingin memperoleh informasi dari orang lain dengan mengajukan pertanyaan, berdasarkan tujuan tertentu. Wawancara dilakukan langsung di lokasi penelitian dengan memanfaatkan informasi dari informan itu sendiri.

Wawancara yang dilakukan dalam penelitian ini untuk mengetahui persepsi dari kedua informan penelitian mengenai penggunaan e-book. Pertanyaan wawancara mengacu pada teori (Marshall \& Rossman, 2011), (Fontana \& Prokos, 2007) dan (Turner III, 2010), serta penelitian Lim (2013). Peneliti mengaitkan technology acceptance model dengan persepsi guru. Hasilnya untuk menguji bagaimana guru melakukan gerakan perubahan untuk mendapatkan pengetahuan melalui penggunaan ebook (mobilitas) mengidentifikasi sarana yang digunakan guru untuk mendapatkan pengetahuan (fasilitas), kendala yang dihadapi guru ketika menggunakan e-book (Resistance to Change) kepercayaan guru dalam mendapatkan hasil dari penggunaan ebook (Self-Efficacy).

3. Observasi dan Wawancara Penelitian

Pada tahapan ini peneliti menggabungkan hasil observasi dan wawancara untuk kemudian dianalisa dan diolah sesuai dengan tujuan penelitian. Terkadang apa yang diperoleh selama observasi, tidak sama dengan hasil yang diperoleh pada saat wawancara. Sehingga perlu disinkronkan antara kedua teknik pengumpulan data penelitian tersebut guna mendapatkan hasil sevalid mungkin.

Istilah observasi berasal dan bahasa Latin yang berarti "melihat" dan "memperhatikan". Istilah observasi diarahkan pada kegiatan memperhatikan secara akurat. Observasi menjadi bagian dalam penelitian berbagai disiplin ilmu, baik ilmu eksakta maupun ilmu-ilmu social.

Observasi yang berarti pengamatan bertujuan untuk mendapatkan data tentang suatu masalah, sehingga diperoleh pemahaman atau sebagai alat re-checkingin atau pembuktian terhadap informasi / keterangan yang diperoleh sebelumnya. Sebagai metode ilmiah observasi biasa diartikan sebagai pengamatan dan pencatatan fenomenafenomena yang diselidiki secara sistematik.

Wawancara adalah suatu percakapan antara dua atau lebih orang yang dilakukan oleh pewawancara dan narasumber. Ada juga yang mengatakan bahwa definisi wawancara adalah suatu bentuk komunikasi lisan yang dilakukan secara terstruktur oleh dua orang atau lebih, baik secara langsung maupun jarak jauh, untuk membahas dan menggali informasi tertentu guna mencapai tujuan tertentu pula.

Observasi mencatat fenomena yang muncul, dan mempertimbangkan hubungan antar aspek dalam fenomena tersebut. Observasi dapat berlangsung dalam 
konteks laboratoriurn maupun konteks alamiah. Dalam arti yang luas observasi sebenarnya tidak hanya terbatas kepada pengamatan yang dilakukan, baik secara langsung maupun tidak langsung. Pengamatan tidak langsung misalnya melalui questionnaire dan tes.

Wawancara memiliki tujuan yang jelas dan memiliki makna yang melebihi maksud dari percakapan biasa. Proses wawancara ini terjadi dengan adanya komunikasi bolak-balik antara pewawancara dengan orang yang diwawancarai, untuk menggali topik tertentu yang dibahas.

Jadi penggunaan metode Observasi dan Wawancara sangat penting dalam penelitian kualitatif. Mengingat dari proses tersebut dapat dilakukan proses triangulasi data maupun sumber. Dari kedua metode pengumpulan data tersebut terdapat perbedaan diantaranya adalah dilihat dari aktivitas yang dilakukan dan prosedurnya berakhir dengan hasil yang berbeda, tujuan untuk observasi dan wawancara berbeda.

Analisis data yang digunakan dalam penelitian ini menggunakan teknik analisis data dengan metode fenomenologi. Creswell (2015: 254-265) menyatakan bahwa fenomenologi merupakan studi yang mendeskripsikan persepsi umum sejumlah individu terhadap pengalaman terhadap suatu fenomena atau konsep tertentu. Adapun langkah-langkah yang dilakukan pada penelitian fenomenologi yaitu mengorganisasikan data, membaca dan membuat kesimpulan, mendeskripsikan data, mengklasifikasikan data, menafsirkan data, menyajikan data (Creswell, 2018). a) Mengorganisasikan Data Penelitian. Pada tahap ini peneliti mengorganisir data dalam file di komputer, dan memisahkan data. Data dipisahkan sesuai dengan hasil teknik pegumpulan data yang berbeda maupun informan yang berbeda. b) Membaca dan Membuat Memo Penelitian. Pada tahap ini peneliti membaca kembali data-data yang telah ditranskip, mencoba memaknai data sebelum memecahkan menjadi bagian-bagian. Sementara itu pada saat membaca peneliti juga akan membuat memo sebagai penanda pada transkip yang dibaca untuk mempermudah eksplorasi data. Kesimpulan yang dituliskan berupa ide atau konsep penting yang muncul. c) Mendeskripsikan, Mengklasifikasikan Dan Menafsirkan Data Menjadi Kode Dan Tema pada tahap ini peneliti mendeskripsikan secara detail pengalaman personal. Mengembangkan tema atau dimensi dari deskripsi data yang telah dilakukan, dan memberikan penafsiran menurut sudut pandang peneliti dan dari perspektif yang ada dalam literatur. Informan dalam penelitian ini guru tentang penggunaan e-book. Dalam penelitian ini peneliti menggunakan Technology acceptance model sebagai kerangka kerja pengkodean pada hasil wawancara peserta didik dan guru. Proses pengkodean dimulai dengan mengelompokkan data teks menjadi kategori informasi lebih kecil, mencari bukti untuk kode tersebut dari berbagai database yang digunakan dalam studi, kemudian memberi label pada kode tersebut. d) Menyajikan Data Penelitian Tahap ini dilakukan dengan mengemas dan meyajikan data yang diolah dalam bentuk teks, tabel atau gambar yang peneliti temukan. Hasil yang ditemukan yang disajikan pada bab pembahasan akan dikaitkan dengan hasil penelitian yang relevan

\section{HASIL DAN PEMBAHASAN}

Hasil penelitian ini merujuk pada fokus penelitian yang diacu pada BAB I pendahuluan. Hasil penelitian mengenai persepsi guru tentang penggunaan E-book dalam pembelajaran teknik komputer dan jaringan di SMK Negeri 1 Gedung Aji Kabupaten Tulang Bawang diperoleh secara wawancara langsung terhadap ketua 
program keahlian dan guru Teknik Komputer dan Jaringan SMK Negeri 1 Gedung Aji Kabupaten Tulang Bawang.

Temuan mengenai persepsi guru tentang penggunaan e-book pada pembelajaran Teknik Komputer dan Jaringan. Kerangka kerja yang digunakan untuk menganalisis persepsi guru tentang penggunaan e-book ialah Technology acceptance model (TAM) di sajikan berikut ini.

1. Persepsi Guru Mengenai Penggunaan E-Book

Pada poin ini peneliti membahas mengenai persepi guru tentang e-book. E-book merupakan sumber bacaan yang berisi banyak konten dari mulai materi pembelajaran, bacaan ringan, keagamaan dan sebagainya. E-book menjadi salah satu yang digunakan pencari ilmu di seluruh dunia untuk mencari sumber pembelajaran, karena dinilai lebih update dan lebih efisien. Dari e-book kita tidak hanya mengetahui sumber pembelajaran dari ruang lingkup kecil melainkan dari ruang lingkup besar. Selain itu, sumber-sumber pembelajaran yang digunakan dari berbagai negara.

Variasi. Terkait dengan Rencana strategis Kemendikbud mengenai mewujudkan pembelajaran yang bermutu sesuai lingkup standar nasional serta memfokuskan akan keberagaman. Jadi, dapat diartikan sebagai keberagaman informasi yang didapat untuk meningkatkan mutu pembelajaran. Hal tersebut sesuai dengan yang diungkapkan oleh G5 berikut "tidak hanya materi pelajaran, akan tetapi banyak konten lainnya yang menjadi hiburan bagi peserta didik. Saya juga sering mencari konten keagamaan melalui e-book. Jadi tidak hanya sekedar untuk pembelajaran, tapi hal-hal lainnya" (fasilitas). G5 menekankan bahwa penggunaan e-book lebih beragam, tidak hanya berisi materi pelajaran akan tetapi bisa bersifat menyenangkan. Sependapat dengan G5, G1 mengungkapkan bahwa "buku cetak bukan satu-satunya sumber ilmu. Contoh lain bisa mencari melalui artikel-artikel dan contoh-contoh real dari perusahaan (fasilitas)" G1 menekankan bahwa perlunya mencari tambahan materi selain yang ada dibuku cetak. G1 mengungkapkan bahwa buku cetak bukan satu-satunya sumber ilmu. Melainkan banyak sumber ilmu lain yang bisa didapat seperti melalui artikel dan mendatangi langsung perusahaan maupun instansi yang berkaitan dengan teknik komputer dan jaringan ataupun mencari melalui website resminya.

Wawasan. Terkait dengan Rencana strategis Kemendikbud tentang Peningkatan Mutu dan Relevansi Pembelajaran yang Berorientasi pada Pembentukan Karakter. Hal tersebut dapat diartikan sebagai pengembangan wawasan untuk mendapatkan pengetahuan. Sejalan dengan pendapat G5 yang mengungkapkan bahwa penggunaan ebook "bagus karena mempermudah mencari materi pembelajaran, juga menambah wawasan (self-efficacy)". G5 menekankan bahwa penggunaan e-book membantu menambah wawasan karena berisi berbagai macam bacaan. Terkait technology acceptance model. G5 meyakini untuk mendapat pengetahuan yang lebih luas (selfefficacy).

Kemudahan. Terkait dengan paradigma pembangunan pendidikan dan kebudayaan yang di dalamnya terdapat kata "Setiap orang berhak mengembangkan diri melalui pemenuhan kebutuhan dasarnya, berhak mendapat pendidikan dan memperoleh manfaat dari ilmu pengetahuan dan teknologi, seni dan budaya, demi meningkatkan kualitas hidupnya dan demi kesejahteraan umat manusia". Hal tersebut sesuai dengan kegunaan e-book dalam hal mempermudah memperoleh pengetahuan. Sejalan dengan pendapat G1 yang mengungkapkan bahwa

Tidak ada masalah, bagus ya, artinya peserta didik juga bisa saya minta untuk mendownload materi, dan mereka bisa langsung mendownload, mereka bisa belajar 
dirumah, kemudian mereka bisa belajar lewat handphone juga karena rata-rata e-book berbentuk pdf, saya mudah memberitahu mereka jika saya ingin menyuruh mereka membuka materi mengenai "menerapkan jaringan berbasis WAN" mereka akan langsung membuka e-book tersebut (self-efficacy).

G1 menekankan bahwa penggunaan e-book lebih fleksibel dan praktis. Munculnya teknologi seperti e-book, peserta didik dapat dengan mudah mencari materi, serta mempelajarinya di mana saja dan kapan saja hanya melalui handphone.

Efisien. Terkait dengan Rencana strategis menggunakan istilah efisien dalam Meningkatkan efisiensi pendidikan dan pelatihan kerja dengan kebutuhan pembangunan daerah, dengan strategi penyelarasan pendidikan dan pelatihan kerja yang dilakukan oleh pemerintah dan swasta sesuai kebutuhan pembangunan daerah, terutama kebutuhan pusat-pusat pertumbuhan ekonomi dan pembangunan berbasis kemaritiman. G5 menganggap efisiensi penggunaan e-book sebagai berikut ini :

Mungkin tergantung zamannya, kalau saya kan bisa dibilang zaman old ya, menurut saya, saya membaca melalui layar hp itu tidak terlalu bisa memahami inti yang dibaca, karena mungkin zaman dulu gak ada e-book, serta terbiasa menggunakan buku. Kalau saya masih bisa cepat konsentrasi menggunakan buku cetak, karena kalau bagi saya pribadi, hp kan layarnya kecil jadi harus geser kesana kesini bagi saya mengganggu konsetrasi. (Resistance to Change)

G5 menekankan bahwa penggunaan e-book harus sesuai dengan umur dan zaman pemakainya. Hal tersebut berkaitan dengan Resistance to Change dimana G5 menganggap penggunaan e-book membuat kurang memahami inti bacaan, sehingga lebih konsentrasi menggunakan buku cetak. Sedikit berbeda dari G5, G1 menyatakan penggunaan e-book efisien untuk membantu peserta didik dalam belajar. Karena sangat fleksibel dan mempermudah peserta didik dalam belajar. Sebagaimana yang diungkapkan berikut

Efisien ya, jadi peserta didik bisa membaca kapanpun dia akan belajar, apalagi peserta didik zaman sekarang ya, dengan handphone mereka terlalu bersahabat, mereka mudah mengakses internet dan sering membaca melalui handphone. (Self-Efficacy)

G1 mengintepretasikan penggunaan e-book sangat efisien, karena peserta didik dapat belajar kapanpun mereka ingin belajar. Keinginan untuk belajar itu tergantung mood masing-masing sehingga penggunaan e-book mampu memudahkan apabila seseorang dalam mood ingin membaca. Secara keseluruhan Mengenai efisienkah penggunaan e-book. G5 lebih menekankan tergantung umur penggunanya. Menurut G5, guru yang sudah berumur kan zamannya dulu tidak menggunakan e-book kemungkinan tidak akan berkonsentrasi membuka dan membaca menggunakan e-book. Sementara G1 mengungkapkan bahwa penggunaan e-book efisien karena membantu peserta didik mendapatkan pengetahuan yang lebih luas dan dapat membaca kapanpun peserta didik ingin belajar.

Kebutuhan. Terkait dengan paradigma pembangunan pendidikan dan kebudayaan yang di dalamnya terdapat kata Setiap orang berhak mengembangkan diri melalui pemenuhan kebutuhan dasarnya". Hal tersebut diartikan sebagai kebutuhan dalam mencari sumber pembelajaran. Sebagaimana yang diungkapkan G1 sebagai berikut "Biasa saja ya, tergantung kebutuhan, saat memang ada e-book, saya akan membaca e-book. E-book juga berguna untuk mencari tambahan-tambahan materi selain yang ada di buku cetak, (mobilitas)"

Wawancara di atas dapat disimpulkan bahwa bagi G1 penggunaan e-book, lebih digunakan sesuai kebutuhan. Karena jika ada e-book. maka G1 lebih memilih 
menggunakan e-book. Secara keseluruhan, G5 maupun G1 memiliki persamaan dan perbedaan dalam memandang penggunaan e-book. G5 dan G1 sama-sama berfokus pada variasi ketika menggambarkan mengenai penggunaan e-book. Selain itu, G5 berfokus pada wawasan, relevan, dan kombinasi ketika menggambarkan mengenai penggunaan e-book. Sementara G1 berfokus pada kemudahan dan kebutuhan ketika menggambarkan mengenai penggunaan e-book.

Sehubung dengan Technology acceptance model, dari hasil wawancara G5 dalam hal variasi berkaitan dengan fasilitas. Sementara, wawasan berkaitan dengan self-efficacy. selanjutnya relevan berkaitan dengan resistance to change. Terakhir, kombinasi berkaitan dengan mobilitas. lain halnya, G1 dalam hal kemudahan berkaitan dengan self-efficacy. sementara kebutuhan berkaitan dengan fasilitas.

Terkait dengan temuan yang kemudian akan dibahas pada bab selanjutnya, tentu berkaitan dengan faktor pendukung persepsi guru terkait penggunaan e-book, dan juga terkait kelebihan maupun kekurangan saat menggunakan e-book dalam pembelajaran teknik komputer dan jaringan. Pada dasarnya, temuan-temuan tersebut selanjutnya menjadi bahan dalam menganalisa terkait model penelitian yang menggunakan pendekatan technology acceptance model (TAM).

\section{Pembelajaran Teknik Komputer dan Jaringan}

SMK Negeri 1 Gedung Aji Kabupaten Tulang Bawang memiliki salah satu program keahlian yang menarik minat banyak peserta didik, yaitu Teknik Komputer dan Jaringan. Sebagai salah satu jurusan favorit, tentu ada tantangan tersendiri dalam mengemas metode pembelajaran agar menjadi lebih menarik dan tentu menggunakan pendekatan teknologi dalam penerapan media pembelajarannya.

Ada tiga kelompok mata pelajaran yang menjadi dasar pengembangan keahlian dalam program keahlian Teknik Komputer dan Jaringan. Antara lain dasar bidang keahlian (C1), dasar program keahlian (C2) dan kompetensi keahlian (C3). Masingmasing bidang tersebut memiliki muatan mata pelajaran yang saling berkesinambungan dan menjadi pendukung satu sama lain. Muaranya adalah terkait produk kreatif atau kewirausahaan yang menggambarkan berhasil tidaknya suatu kompetensi keahlian di sekolah menengah kejuruan.

Berdasarkan hasil wawancara dan observasi dari guru dalam penelitian ini, didapati bahwa G5 dan G1 sama-sama mengajar untuk mata pelajaran produktif. Namun demikian, intensitas penggunaan e-book selama pembelajaran dari keduanya berbeda. Hal tersebut karena adanya perbedaan persepsi dari sisi resistance to change dalam penggunaan teknologi. Namun demikian, dari sisi konten pembelajaran, G1 dan G5 sama-sama menguasai materi yang diajarkan. Hanya saja model dan gaya belajarnya yang berbeda.

G5 lebih banyak menggunakan buku paket dalam pembelajaran. Media belajar seperti e-book hanya sebagai complement saja. Artinya hanya sebatas pelengkap apabila ada kekurangan pada buku paket. Gaya belajar lebih kepada guru sentris yang berarti guru lebih dominan selama proses pembelajaran. Sehingga aktifitas peserta didik kurang. Namun tetap semua sesuai dengan kurikulum dan target dalam rencana pelaksanaan pembelajaran.

Berbeda dengan G1 yang lebih dapat menerima perkembangan teknologi sehingga dengan percaya diri menjadi seperti perpustakaan berjalan. Buku paket tidak begitu menjadi acuan utama dalam belajar. Kegiatan pembelajaran lebih merdeka, karena peserta didik diberi kebebasan selama belajar. Yang terpenting tujuan dari 
pembelajaran terpenuhi. Peserta didik menjadi pelaku utama dalam proses pembelajaran. Guru sebagai fasilitator, sehingga peserta didik lebih aktif.

Terlebih dimasa pandemic covid 19, ketika pembelajaran dilakukan secara daring, baik G1 maupun G5 memanfaatkan teknologi dalam proses pembelajarannya. Materi dan tugas disusun sedemikian rupa supaya mudah dipahami, dimengerti dan dapat diakses dimana saja. Tentu penggunaan e-book menjadi solusi dalam memberikan pembelajaran. Pemanfaatan teknologi menjadi sangat membantu selama proses pembelajaran di masa pandemi.

Dengan fasilitas dan sarana prasarana yang dimiliki, pembelajaran dengan metode daring tentu ada sisi baik dan buruknya. Bagi G1 maupun G5 karena memang telah berkecimpung dalam program keahlian teknik komputer dan jaringan, tentu bukan menjadi kendala yang berarti. Berbeda dengan guru dari program keahlian yang lain. Walau demikian, sesama guru yang sering bertemu di ruang kantor, saling berbagi dan memberi informasi terkait strategi-strategi yang harus dikerjakan selama proses pembelajaran daring supaya program pembelajaran tetap berjalan sesuai target.

Namun tentu ada banyak hal yang menjadi temuan selama proses pembelajaran yang dilakukan secara virtual. Sehingga menjadi salah satu masukan bagi institusi terutama SMK Negeri 1 Gedung Aji Kabupaten Tulang Bawang dalam proses pembelajaran di masa pandemi. Terlebih menghadapi berbagai macam karakter peserta didik. Apabila hanya mempelajari dari buku paket, tentu kurang optimal. Pemanfaatan multimedia dalam proses pembelajaran menjadi mutlak diperlukan. Terlebih pembelajaran teknik komputer dan jaringan lebih menekankan pada keahlian atau skill selama proses pembelajarannya.

3. Pembasahan Persepsi Guru Tentang Penggunaan E-Book dalam pembelajaran TKJ (Teknik Komputer dan Jaringan)

Pada pembahasan kali ini, diambil secara umum guna menjawab pertanyaan penelitian pada rumusan masalah yang meliputi tiga rumusan masalah. Yang pertma berkaitan dengan persepsi guru tentang penggunaan e-book dalam pembelajaran TKJ (teknik komputer dan jaringan), kedua guru menyampaikan sangat baik terutama terkait dengan fasilitas serta mobilitas. Masing-masing guru sepakat, bahwa dengan adanya ebook menjadi terbantu dalam hal memberikan referensi pembelajaran yang bervariasi pada peserta didik (fasilitas).

Selain itu juga dapat memberikan kemudahan terkait dengan kemudahan akses dalam memperoleh ilmu yang terus berkembang. Hal tersebut dikarenakan berkembangnya teknologi informasi dapat memudahkan guru membuka e-book pada perangkat seperti HP (gadget), komputer maupun laptop. Sehingga dapat dibuka dimana saja dan kapan saja (mobilitas).

Meski demikian, berdasarkan pemaparan dari G5 masih ada kelemahan dari penggunaan e-book sebagai salah satu media pembelajaran. Diantaranya dikarenakan penggunaan e-book yang dibuka pada handpone (HP) dirasa font terlalu kecil. Selain itu, faktor kelelahan mata karena radiasi cahaya layar juga menjadi alasan. (resistence to change).

Namun secara tidak langsung, masing-masing guru sepakat gahwa dengan adanya media pembelajaran seperti e-book mereka jadi dapat lebih leluasa memberikan tugas ataupun materi tambahan kepada peserta didik. Sehingga peserta didik juga jadi lebih banyak menerima referensi atau acuan dalam belajar. Tidak monotan hanya pada satu media saja. Masing - masing guru percaya bahwa dengan cara ini, peserta didik 
menjadi lebih aktif dalam pembelajaran. Karena mereka memiliki banyak referensi dalam belajar. (Self efficacy).

Terkait dengan kendala dan solusinya, ada beberapa aspek yang menjadi perhatian. Seperti misalnya terkait dengan font yang terlalu kecil, maka dapat disiasati dengan memperbesar ukuran font dengan fasilitas zoom in yang saat ini telah ditanamkan pada perangkat-perangkat terbaru. Adapun berkaitan dengan kapasitas atau keterbatasan media penyimpanan, tentu bisa digunakan media penyimpanan eksternal seperti flashdisk, hardisk eksternal, bahkan USB OTG. Koneksi internet yang lambat atau terbatasnya kuota data, dapat disiasati dengan memanfaatkan proses transfer data secara offline, bisa menggunakan hotspot tethering, bluetooth atau kirim secara langsung menggunakan kabel data maupun perangkat penyimpanan yang lain.

\section{KESIMPULAN DAN SARAN}

\section{KESIMPULAN}

Berdasarkan tujuan penelitian disimpulkan bahwa Guru Teknik Komputer dan Jaringan di SMK Negeri 1 Gedung Aji Kabupaten Tulang Bawang mempersepsikan penggunaan e-book sebagai kemudahan dalam mencari bahan ajar dan dapat memberi wawasan yang luas kepada peserta didik. Materi yang disampaikan oleh guru sangat positif menjadikan pembelajaran siswa menjadi lebih aktif. Kendala yang dirasakan guru jurusan teknik komputer dan jaringan yaitu jaringan internet yang lemah, memerlukan kapasitas memori yang besar, memerlukan perangkat elektronik yang canggih, memerlukan baterai handphone yang besar, memerlukan kuota internet yang banyak dan ukuran font yang kecil.

\section{SARAN}

Penelitian selanjutnya diharapkan mengembangkan aplikasi e-book yang lebih menarik berisi gambar maupun kata-kata serta relevan untuk belajar materi terkait Teknik Komputer dan Jaringan.

\section{DAFTAR PUSTAKA}

Birt, J., \& Cowling, M. A. (2016). Mixed reality in higher education: Pedagogy before technology.

Carliner, Saul. (2015). Extended Abstract: Perceptions and e-Textbooks: Insights into Challenges Faced by Publishers. Institute of Electrical and Electronics Engineers. 1-2. DOI: 10.1109/IPCC.2015.7235784.

Carmen Anton, Carmen Camarero, and Javier Rodriguez. (2013). Usefulness, Enjoyment, and Self-Image Congruence: The Adoption of e-book Readers. Psychology and Marketing. Inc. DOI: 10.1002/mar.20612

Creswell, J. W. (2015). Penelitian kualitatif \& desain riset memilih diantara lima pendekatan edisi ketiga (terjemahan Ahmad Lintang Lazuardi). Yogyakarta: Pustaka Pelajar. (Edisi asli diterbitkan tahun 2013 oleh SAGE Publication, Inc.). 
Churchill Daniel. (2017). Digital Resources for Learning. Springer Texts in Education. ISBN 978-981-10-3775-7. DOI 10.1007/978-981-10-3776-

Abdul Majid. (2008). Perencanaan Pembelajaran, Mengembangkan Standar Kompetensi Guru. Jakarta: PT. Rosda Karya

AECT (Association for Educational Communication and Technology). (1976). Evaluating Media Programs District and School, Washington, D.C : The Association.

Anuradha, K.T. and Usha, H.S. (2005), -Use of e-books in an academic and research environment - a case study from the Indian Institute of Science", Program: Electronic Library and Information Systems, Vol. 40 No. 1, pp. 48-62.

Baron \& Byrne. (2000). Social Psychology. (9th Edition). Massachusetts: A Pearson Education Company.

Batada, Ibrahim. 2002. Managemen Perlengkapan Sekolah. Bumi Aksara

Bereiter, C., \& Scardamalia, M. (2003). Learning to work creatively with knowledge. In E. De Corte, L. Verschaffel, N. Entwistle, \& J. van Merriënboer(Eds.), Powerful learning environments: Unravelling basic components and dimensions (pp. 55-68). Bingley, UK: Emerald Publishing. Retrieved from http://ikit.org/fulltext/inresslearning.pdf.

Birt, J., \& Cowling, M. A. (2016). Mixed reality in higher education: Pedagogy before technology.

De Jong, M. T., \& Bus, A. G. (2003). How well suited are electronic books for supporting literacy?. Journal of Early Childhood Literacy, 3 (2), 147-64.

Depdikbud. (1982). Psikologi Pendidikan. Jakarta: Dirjen PT

Desmita. (2011). Psikologi Perkembangan Peserta Didik. Bandung: PT. Remaja Rosdakarya.

(2016). Psikologi Perkembangan Peserta Didik. Bandung: PT. Remaja Rosdakarya.

Dimyati Mahmud. (2001). Psikologi Suatu Pengantar. Yogyakarta : BPFEDillon, D. (2001), -E-books: the university of Texas experience, part 1\|, Library Hi Tech, Vol. 19 No. 2, pp. 113-25.

Duhaney, D.C. and Zemel, P.C. (2000), -Technology and the educational process: transforming classroom activities $\|$, International Journal of Instructional Media, Vol. 27 No. 1, pp. 67-72.

Education and early childhood development. (2008). Evaluation and Selection of Learning Resources: A guide. Prince Edward Island : epartment of Education. 
Eveline Siregar dan Hartini Nara. (2010). Teori belajar dan Pembelajaran. Bogor: Ghalia Indonesia.

Fishbein, M. and Aijzen, I. (1975), Belief, Attitude, Intention and Behaviour: An Introduction to Theory and Research, Addison-Wesley, Reading, MA

Fontana, A., Prokos, A. H. (2007). The interview: From formal to post-modern. Walnut Creek, CA: Left Coast. 